\title{
Carcinoma en cuirasse in a young female
}

\author{
Sahaj Prajapati, Manu Vats, Anshul Goel, Arihant Jain
}

Department of General Surgery, Maulana Azad Medical College, New Delhi, India

\section{Correspondence to \\ Dr Manu Vats,}

vatsmanu@gmail.com

Accepted 27 October 2017

\section{DESCRIPTION}

Cancer or carcinoma en cuirasse is an infrequent clinical presentation of metastatic cutaneous carcinoma. ${ }^{1}$ In this condition, the skin of the chest wall is studded with carcinomatous indurated plaques. It is often seen after a patient of breast cancer undergoes mastectomy operation and develops local recurrence. The patient usually presents after a few months or years after the surgery ${ }^{2}$ (figure 1 ). This patient, a 22-year-old woman, had already undergone right modified radical mastectomy for infiltrating ductal carcinoma (IDC) Not Otherwise Specified (NOS) grade II with triple-negative receptor status, 1 year ago. She had now presented with a lump in the left breast and multiple cutaneous lesions on the chest wall on the right side and on the left breast since the past 5 months (figure 2). Cutaneous metastasis or carcinoma en cuirasse has occurred on the right side after mastectomy, whereas they are a part of the initial presenting symptom on the contralateral side. The patient also had multiple fixed right axillary lymph nodes and a left supraclavicular node; both came positive for malignancy. Core needle biopsy was suggestive of IDC NOS grade II with Estrogen Receptor (ER), Progesterone Receptor (PR) and Human Epidermal Growth factor receptor 2 (HER2/ neu) negative status. Only one cycle of docetaxel injection and oral capecitabine was given by the medical oncologist as palliative therapy, at the time of writing this case. However, electrochemotherapy is an impressive modality of palliative treatment of cutaneous metastasis in the recurrence of carcinoma breast after undergoing surgery and radiation therapy. ${ }^{3}$ Unfortunately, this therapy was not available at our centre.

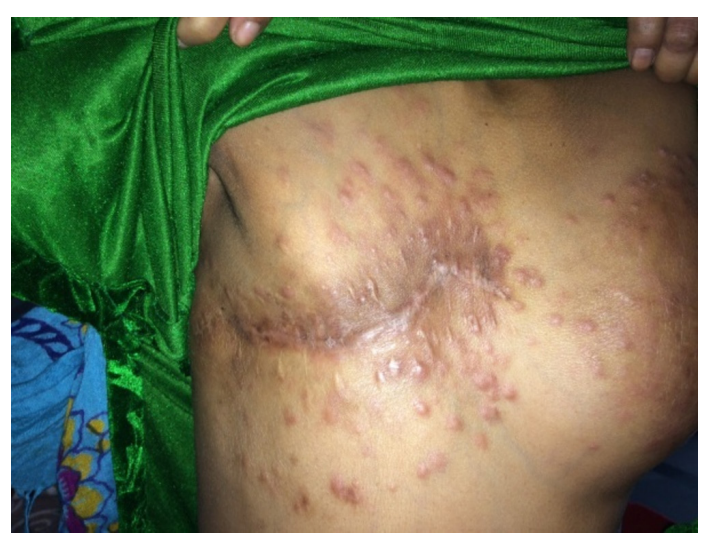

Figure 1 Cutaneous metastasis (cancer en cuirasse) after right modified radical mastectomy.

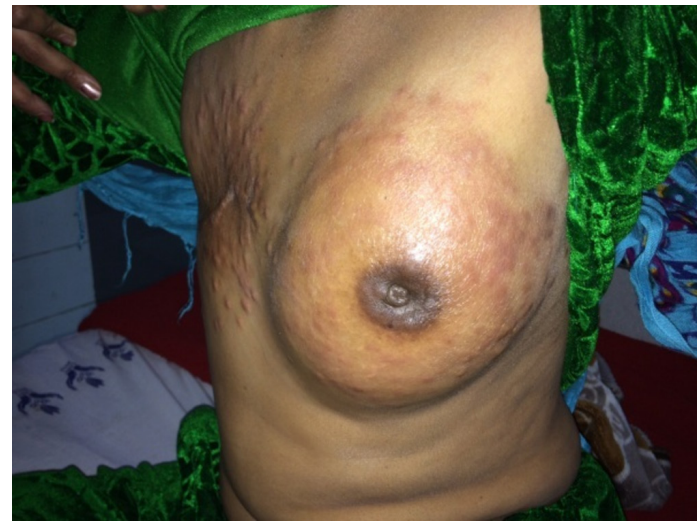

Figure 2 Left breast showing cutaneous metastatic nodules with inversion of nipple.

\section{Learning points}

- Carcinoma en cuirasse, along with a breast lump, can be a presenting symptom in carcinoma breast as well as present as local recurrence on the mastectomy site.

- Carcinoma en cuirasse can also be seen in young patients with an aggressive primary tumour.

Contributors All the authors have contributed to the conception or design of the work, the acquisition, analysis and interpretation of data. They have drafted the work, revised it critically for important intellectual content. They have given the final approval of the version published. They agree to be accountable for all aspects of the work in ensuring that questions related to the accuracy or integrity of any part of the work are appropriately investigated and resolved.

Competing interests None declared.

Patient consent Obtained.

Provenance and peer review Not commissioned; externally peer reviewed.

(C) BMJ Publishing Group Ltd (unless otherwise stated in the text of the article) 2017. All rights reserved. No commercial use is permitted unless otherwise expressly granted.

\section{REFERENCES}

1 Lee SH, Cheng HM, Cheng SF, et al. Breast carcinoma en cuirasse - a case report and literature review. Dermato/ Sinica 1993;11:129-35.

2 Mahore SD, Bothale KA, Patrikar AD, et al. Carcinoma en cuirasse: a rare presentation of breast cancer. Indian J Pathol Microbiol 2010;53:351-8.

3 Schmidt G, Juhasz-Böss I, Solomayer EF, et al. Electrochemotherapy in breast cancer: a review of references. Geburtshilfe Frauenheilkd 2014;74:557-62. 
Copyright 2017 BMJ Publishing Group. All rights reserved. For permission to reuse any of this content visit http://group.bmj.com/group/rights-licensing/permissions.

BMJ Case Report Fellows may re-use this article for personal use and teaching without any further permission.

Become a Fellow of BMJ Case Reports today and you can:

- Submit as many cases as you like

- Enjoy fast sympathetic peer review and rapid publication of accepted articles

Access all the published articles

- Re-use any of the published material for personal use and teaching without further permission

For information on Institutional Fellowships contact consortiasales@bmjgroup.com

Visit casereports.bmj.com for more articles like this and to become a Fellow 